\title{
THE ROLE OF ORGANIZATIONAL SUPPORT IN THE RELATIONSHIP BETWEEN INDIVIDUAL AND ORGANIZATIONAL LEARNING
}

\author{
BRUNO C. CORREIA-LIMA ${ }^{1}$ \\ (iD) http://orcid.org/0000-0003-0049-8788 \\ ELISABETH LOIOLA ${ }^{2}$ \\ (iD) https://orcid.org/0000-0003-3759-9048 \\ CICERO R. PEREIRA ${ }^{3}$ \\ (iD) https://orcid.org/0000-0003-3406-3985 \\ JOSIMAR S. COSTA 4 \\ (iD) https://orcid.org/0000-0002-7128-8908 \\ CLÁUDIO B. LEOPOLDINO ${ }^{1}$ \\ (iD) https://orcid.org/0000-0002-5618-721X
}

To cite this paper: Correia-Lima, B. C., Loiola, E., Pereira, C. R., Costa, J. S., \& Leopoldino, C. B. (2019). The role of organizational support in the relationship between individual and organizational learning, Revista de Administração Mackenzie, 20(5). doi:10.1590/1678-6971/eRAMG190016

Submission: Feb. 7, 2019. Acceptance: June 13, 2019.

\footnotetext{
1 Universidade Federal do Ceará (UFC), Fortaleza, CE, Brazil.

2 Universidade Federal da Bahia (UFBA), Salvador, BA, Brazil.

3 Universidade Federal da Paraíba (UFPB), João Pessoa, PB, Brazil.

4 Universidade de Fortaleza (Unifor), Fortaleza, CE, Brazil.
}

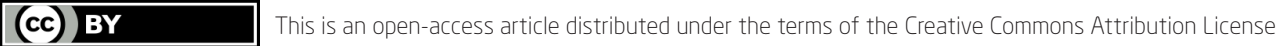

\footnotetext{
This paper may be copied, distributed, displayed, transmitted or adapted if provided, in a clear and explicit way, the name of the journal, the edition, the year and the pages on which the paper was originally published, but not suggesting that RAM endorses paper reuse. This licensing term should be made explicit in cases of reuse or distribution to third parties. It is not allowed the use for commercial purposes.

Este artigo pode ser copiado, distribuído, exibido, transmitido ou adaptado desde que citados, de forma clara e explícita, o nome da revista, a edição, o ano e as páginas nas quais o artigo foi publicado originalmente, mas sem sugerir que a RAM endosse a reutilização do artigo. Esse termo de licenciamento deve ser explicitado para os casos de reutilização ou distribuição para terceiros. Não é permitido o uso para fins comerciais.
} 


\section{ABSTRACT}

Purpose: To understand the relationship between the outcomes of individual learning (IL) of competencies and the outcomes of organizational learning (OL) of competencies, as well as the mediating role of organizational support for transfer (OST) of learning in the conversion of IL into OL.

Originality/value: Measurement of OL in relation to IL since, as a rule, research on OL presupposes IL, without stepping back to measure it. Proposing socialization and codification as OL processes, which involves formal and informal learning, and tacit and explicit knowledge. Focus on converting IL results in organizations into learning of the organization, allowing a more accurate assessment of the results of organizational investments in formal and informal learning, considering the current practice of measuring T\&D exclusively. Proposing the use of OST to enhance processes and results of IL and conversion of IL into OL. The use of exploratory and confirmatory modeling methods and data from two different organizations are aligned with good practice in the research field.

Design/methodology/approach: The hypotheses were tested in two studies, carried out with validated scales, sent by the organizations via a link emailed to the respondents. Study 1, exploratory, involved 203 employees of a public bank and study 2, confirmatory, with 252 employees of a Civil Society Organization of Public Interest (CSOPI).

Findings: The two studies show that there were IL and OL, that IL is net learning of competencies desired by the organization $\left(\mathrm{IL}_{1}-\mathrm{IL}_{0}\right)$, that $\mathrm{OL}$ is the result of socialization and codification of IL applied to work, that IL predicts OL, and that OST mediates the relationship between IL and OL.

\section{KEYWORDS}

Individual learning of competencies. Organizational learning. Socialization. Codification. Organizational support for transfer. 


\section{INTRODUCTION}

Learning is a basic individual process. Its effects can, however, spread to other levels of the learning continuum: teams and organizations (Argyris \& Schön, 1978). Organizations can learn but in a way different from individuals (Nelson \& Winter, 1982; Levitt \& March, 1988). The lack of differentiation between individual learning (IL) and organizational learning (OL) present in parts of the literature carries two risks: it ignores the role of workers in the construction and renewal of organizational knowledge, anthropomorphizing the organizations, or equates OL with IL, disregarding the complexity of the organizations (Kim, 1993) and their learning systems (Argyris \& Schön, 1978).

The worker learns (IL) in events structured and directed by the organizations (formal learning) and also informally throughout his/her working day (Manuti, Pastore, Scardigno, Giancaspro, \& Morciano, 2015). However, studies focusing on both formal and informal learning are rare (Watkins \& Marsick, 2014). In addition, not all IL is applied at work (Reinhold, Gegenfurtner, \& Lewalter, 2018; Sparr, Knipfer, \& Willems, 2017; Ahmed \& Nawaz, 2015). This poses the problems of transfer of learning and organizational support for transfer (OST) to the OL research field.

Organizational support for transfer (OST) corresponds to the set of organizational practices, structures, and systems that encourage and motivate workers to apply their learning in their work (Blume, Ford, Baldwin, \& Huang, 2010). They are antecedents of the transfer of IL to the work (Sparr et al., 2017). Some forms of organizational support act more on the motivation to transfer, while others more strongly to predict the transfer of learning (Reinhold et al., 2018), showing that there are differences between them (Correia-Lima, Loiola, Pereira, \& Gondim, 2017).

OL is oriented toward organizational objectives and goals, is multilevel, and is based on routines. The means and results of internal learning and with other organizations over time, routines that are learned through socialization, training, imitation, mergers, acquisitions tend to undergo changes if planned organizational goals and results are not achieved (Levitt $\&$ March, 1988). OL also results from the codification of changes in theories in use by workers (Argyris \& Schön, 1978). OL depends on, but is different from, IL, which is a necessary but insufficient condition for OL. For OL to occur, IL has to be applied on the job, socialized and codified, coming to form organizational memory (Argyris \& Schön, 1978; Levitt \& March, 1988). 
Although there is much theoretical consensus around the multidimensionality of OL (Antonacopoulou, 2006; Crossan, Maurer, \& White, 2011), empirical evidences about the relationship between IL and OL are scarces (Schilling \& Fang, 2014), when not contradictories. Reports of the inexistence of evidence of association between IL and OL (e.g., Chan, Lim, \& Keasberry, 2003; Antonacopoulou, 2006) coexist with reports of insignificant impact of IL on OL (Loiola, Pereira, \& Gondim, 2011; Leopoldino, 2012), and even with others about the existence of a positive association between IL and OL (Popadiuk \& Ayres, 2016; Kostopoulos, Spanos, \& Prastacos, 2013; Jyothibabu, Farooq, \& Bhusan Pradhan, 2010; Bido, Godoy, \& Araujo, 2010; Ho, 2008). The relationships between IL and OL are direct (Bido et al., 2010) or mediated by group learning (GL) (Jyothibabu et al., 2010; Kostopoulos et al., 2013). Also, OL scales presuppose that there was IL, without measuring it (Correia-Lima, Loiola, \& Leopoldino, 2017), reinforcing one of the research tracks that equates IL at work with the OL.

This work helps to overcome some of the previously mentioned gaps in the literature. It combines in a non-trivial way, as suggested by Basten and Haamann (2018), approaches to IL, to IL transfer to the work, to OST, and to OL with an adequate measurement method, helping to raise the accuracy of processes of assessing results of IL, of IL application at work, of IL conversion into OL and, consequently, of returns on investments in learning in organizations and from organizations. As organizations learn in different ways and rhythms (Burnes, Cooper, \& West, 2003), the research developed covers two organizations of diverse natures: a bank and a civil society organization of public interest (CSOPI). Taking these postulates as a reference, the objective is to understand the relationship between the results of competencies learning (formal and informal) by workers in the organizations, herein referred to as IL, and organizational learning, measured by socialization and by codification, herein referred to as OL. It is also intended to identify the mediating role of OST in the conversion of IL into OL.

\section{FROM INDIVIDUAL LEARNING (IL) OF COMPETENCIES TO ORGANIZATIONAL LEARNING (OL)}

IL is related to lasting changes in attitudes and behaviors, involving the affective, cognitive, and motor levels. These changes are the fruits of personal reflection and social interaction, and promote flexibility, adaptability, and transformative capacity for the individual (Illeris, 2011). 
Through structured formal learning, prompted by the organization and usually outside of work (e.g., courses, programs for training, development, and education) or spontaneous informal learning, under greater control of the worker and less structured (e.g, self-study, interaction with colleagues, learning by doing), workers learn about their tasks and about behaviors desired by the organization (Watkins \& Marsick, 2014). Traditionally, more attention from organizations and researchers is devoted to the study of formal learning, especially training and development (Miller, 2012; Noe, Clarke, \& Klein, 2014). In an interrelated way, IL, both formal and informal, in work situations, although different, have impact on the transfer of IL of competencies to work and on the results of the work (Watkins \& Marsick, 2014; Ahmed \& Nawaz, 2015; Barros Martins, Zerbini, \& Medina Díaz, 2018).

The literature has shown evidence of the relationship between individual competencies, mobilized knowledge in work situations, and OL (Takahashi, 2017). However, organizational competency is not the sum of the competencies of its workers (Le Boterf, 2003). It can be concluded, therefore, that IL of competencies is different from OL, which brings out the need to explore and delimit the concept of OL.

In a normative and intervention-oriented approach, Argyris and Schön (1978) postulate that theories of individual action, which guide actions, change incrementally or radically when confronted with errors, anomalies, inconsistencies, and incongruities "but not all these changes qualify as OL" (Argyris \& Schön, 1978, p. 17). Incremental and radical changes of theories in use (IL) are converted into OL, if codified in individual images and shared maps (Argyris \& Schön, 1978).

Alternatively, for Levitt and March (1988, p. 320), "Organizations learn when they transform inferences from their history into routines, which come to guide their behavior". These routines include rules, procedures, conventions, strategies, technologies, beliefs, frameworks, paradigms, codes, technologies, and knowledge that support them and simultaneously contradict them. They appear as formal and informal, born of the tradeoff between trajectories of exploitation (greater efficiency through the refinement of existing competencies) and exploration (acquisition of new competencies), and survive the turnover of workers. They are imprinted in the collective memory and are often coherent and enduring, but not always; routines are subjected to incremental changes induced by feedback from the balance between aspirations and outcomes. Routines are taught and maintained by socialization and control (Levitt \& March, 1988).

Levitt and March (1988, p. 320), explicitly referring to Argyris and Schön (1978), affirm that "both the emphasis on routines and on ecology of 
learning differentiate our conception of OL from those dealing mainly with IL within an organization". However, considering the almost universal postulation that learning involves both cognition and action (doing), both under the domain of limited rationality (Odor, 2018; Bontis, Crossan, \& Hulland, 2002), the approach proposed here is inspired by Argyris and Schön (1978) and by Levitt and March (1988), without detriment to its internal consistency. According to this approach, OL is a phenomenon dependent and different from IL (Argyris \& Schön, 1978), but not all IL is applied at work, consequently, IL is not always converted into OL (Aragón, Jiménez, \& Valle, 2014; Blume et al., 2010; Argyris \& Schön, 1978). Organizational support and motivation influence this transfer (Reinhold et al., 2018; Aragón et al., 2014; Blume et al., 2010). The application at work of what was learned by the individual, its socialization, and its codification are pre-requisites for OL, that is, for the substitution of old routines and theories in use by new ones (Reinhold et al., 2018; Aragón et al., 2014; Blume et al., 2010; Argyris \& Schön, 1978; Levitt \& March, 1988).

Based on these theoretical propositions, we ask: "What is the relationship between IL and OL?". The inter-influence between IL and OL supports the formulation of the first hypothesis:

- H1: The greater the IL, the greater the OL.

An ongoing process of learning, socialization (SOC) corresponds to the set of formal and informal practices that promote interaction among the members of the organization with objectives of sharing knowledge about tasks, roles, group processes, and organizational attributes such as climate, culture, mental models, organizational maps, and values (Ostroff \& Kozlowski, 1992), allowing existing and new organizational knowledge to be recursively assimilated, understood, transformed, and used (Mesmer-Magnus \& De Church, 2009). Classical examples of SOC mechanisms are: mentoring, supervision, help from co-workers, observation, trial and error, and reading manuals (Ostroff \& Kozlowski, 1992).

IL and SOC are positively related (Mesmer-Magnus \& De Church, 2009; King, 2009; Ostroff \& Kozlowski, 1992; Burk, 2008) and can be facilitated by communication tools (Kotlarsky, Scarbrough, \& Oshri, 2014). Given this discussion, $\mathrm{H} 1$ develops into:

- H1a: The greater the IL, the greater the SOC.

Codification (COD) is a classic practice of appropriation of workers' knowledge by organizations (Burnes et al., 2003), facilitating access to and 
the re-use of knowledge and identification of people with competencies relevant to the organization (Kotlarsky et al., 2014). COD practices ensure that individual knowledge elements remain in the organization, storing them and making them explicit (Burk, 2008) in norms, procedures, routines, manuals, projects, and in software (King, 2009). Thus, another development from $\mathrm{H} 1$ occurs:

- H1b: The greater the IL, the greater the COD.

The SOC and COD processes are inseparable in complex learning environments, in which the formalization of routines is part of their process of institutionalization. Thus, SOC without COD weakens the relevance, application, and renewal of stored knowledge and OL (Leopoldino, 2012; Noe et al., 2014; Correia-Lima, 2016).

\section{ORGANIZATIONAL SUPPORT FOR TRANSFER OF LEARNING (OST)}

Understanding and conjecturing how IL is converted into OL is very important for the practice of management in organizations. This understanding can enable greater alignment between investments in workers' learning and the performance of workers and organizations. However, as already reported, IL is not always converted to OL, since there appear to be auxiliary variables for the transfer of IL to the work (Barros Martins et al., 2018; Reinhold et al., 2018; Blume et al., 2010), and consequently, the conversion of IL into OL. In this set of possible variables mediating the transformation of IL into OL, this paper highlights organizational support for transfer (OST), an organizational level variable, asking: "What is the role of organizational support for learning transfer in the relationship between IL and OL?".

A two-dimensional complex variable, OST combines material contextual conditions and psychosocial conditions, provided by the organization, which stimulate the application of learning in work situations and favor the conversion of IL into OL (Barros Martins et al., 2018; Reinhold et al., 2018; Pereira, Loiola, \& Gondim, 2016; Blume et al., 2010). OST is a facilitating factor of OL, which leads to:

- $\mathrm{H} 2$ : The greater the OST, the greater the OL. 
OST is divided into material support for transfer (MST) and psychosocial support for transfer (PST) (Reinhold et al., 2018). MST expresses the quantity, quality, and availability of material and financial resources, as well as the adequacy of the physical environment for the transfer of competencies from individuals to the organization (Barros Martins et al., 2018; Reinhold et al., 2018; Pereira et al., 2016). Positive and significant relationships between MST and COD are reported in various studies. The research by Graciola et al., (2016), conducted with industry and service providers in the state of Rio Grande do Sul (Brazil), finds that the perception of physical space, furniture, and equipment is positively related to the logging and communication of knowledge in documents and technological elements of information systems, while Cacciatori, Tamoschus, and Grabher (2012) find a significant relationship between the support of an integrative system and COD in creative industries in various European Union countries. Therefore, H2 develops into:

- H2a: The greater the MST, the greater the COD.

MST is also related to SOC (Congdon, Flynn, \& Redman, 2014; Graciola et al., 2016). The quality of organizational spaces is associated with the transfer and sharing of knowledge between individuals and groups (Graciola et al., 2016, Congdon et al., 2014), just as is the availability of material technological elements (Kotlarsky et al., 2014). Based on this discussion, another development from $\mathrm{H} 2$ is:

- H2b: The greater the MST, the greater the SOC.

PST includes situational factors of managerial, social, workgroup, and organizational support for removing obstacles to learning transfer (Reinhold et al., 2018; Pereira et al., 2016). The influence of different types of PST on SOC of competencies in organizations was the object of various studies. For example, peer support favors the connections between knowledge obtained in the formal training of employees (Aguilera, Dencker, \& Yalabik, 2008). Manager support is also fundamental to the socialization of knowledge among employees (Lin, Wu, \& Lu, 2012; Tasselli, 2015), as well as that from informal networks (Aguilera et al., 2008), while Catino and Patriotta (2013) show tolerance for errors as a support for the socialization of learning in the Italian Air Force. The aligned results of research on PST and SOC support a new development from $\mathrm{H} 2$ :

- H2c: The greater the PST, the greater the SOC. 
Managers play an important role in promoting actions that encourage individuals to store, transfer, share and use acquired knowledge (King, 2009). In addition to the support promoted by superiors, Aguilera et al. (2008) emphasize the support of peers as a stimulus for the development and communication of norms and codified organizational rules. According to the above, another new development from $\mathrm{H} 2$ is:

- H2d: The greater the PST, the greater the COD.

The absence of the institutionalization of IL may derive, for example, from the lack of connection between work requirements and learning (Bontis et al., 2002) or from the absence of OST (Barros Martins et al., 2018; Reinhold et al., 2018) that motivates the workers, leading to wasted investments (Bontis et al., 2002). The perception of OST by employees proves to be positively related to pro-learning postures (Perrot et al., 2014) and positive results for training and development (Barros Martins et al., 2018; Balarin, Zerbini, \& Martins, 2014) and learning (Baranik, Roling, \& Eby, 2010; Perrot et al., 2014). Contexts of sharing (Popadiuk \& Ayres, 2016), of tolerance for errors, with an information system, physical structure, interpersonal incentives (Alvarenga \& Vieira, 2011), among others, favor learning. The literature reviews by Sparr et al. (2017) and Blume et al. (2010) offer strong evidence of the relationship between an environment of support and application of IL at work. But the mediating role of OST in the relationship between IL and OL is still little explored.

The works by Leopoldino (2012) and by Correia-Lima (2016) are two examples of investigation of the mediating role of OST between IL and OL. Upon analyzing these works, one can conjecture that IL is associated with greater use of OST by individuals. As IL is positively associated with OST, and OST is positively associated with OL, then it is quite likely that OST plays a mediating role in the relationship between IL and OL. In this case, we have the last hypothesis to be tested, subdivided into four more specific hypotheses:

- H3: OST mediates the relationship between IL and OL.

- H3a: MST mediates the relationship between IL and SOC.

- H3b: MST mediates the relationship between IL and COD.

- H3c: PST mediates the relationship between IL and SOC.

- H3d: PST mediates the relationship between IL and COD.

The proposed hypotheses were tested in two independent studies which take as objects the IL of competencies and OL in two Brazilian organizations: 
a public bank and a CSOPI working to promote culture and generate income. Study 1 was carried out in the public bank with the objective of conducting an exploratory analysis of the relationships between the variables to ascertain the pertinence of each of the hypotheses, as well as to elaborate an analytical model to systematize the main results. Study 2 was carried out at the CSOPI and had a more confirmatory objective, which allowed evaluation of the quality of the model fit the data by means of structural equation modeling (SEM), in addition to replicating the observed results of study 1 . The use of data from organizations of different natures and of exploratory and confirmatory methods follow good practices in the field of quantitative research (DeVellis, 2003; Morgado, Meireles, Neves, Amaral, \& Ferreira, 2017).

\section{STUDY 1}

Study 1 was conducted with a sample collected at a Brazilian public bank. The objective was to conduct an exploratory analysis of the relationships between the variables and to verify the pertinence of each hypothesis. Specifically, we sought to develop an analytical model that synthesizes the set of proposed hypotheses in order to operationalize the mediating role of MST and PST in the relationship between IL and OL.

\subsection{Method of study 1}

It is characterized as a documentary and as a field study (survey cross-section). The documents analyzed to extract the competencies desired by the organization were: Successors Training Program, Succession Development and Planning, Corporate University Performance Model, and Employee Profile. The competencies identified were included in questionnaires sent by e-mail to the organization's employees.

Just over 1,000 bank employees received the questionnaires, of which 203 made up the final sample. The test power analysis, using WebPower (Zhang \& Yuan, 2018), indicated that the sample is sufficiently large because it has test power greater than $99 \%$ for detecting medium or stronger size effects $(r>.30)$ in the population through multiple regression analyses. Other characteristics of the sample are: mostly males (141), young adults ( $72.4 \%$ of the respondents are up to 40 years old), and persons with two to ten years working in the institution $(75.9 \%) ; 48.7 \%$ have completed college, 
$38.9 \%$ are specialists, $5.4 \%$ have a Master's and $1 \%$ Ph.Ds; $88.2 \%$ are banking analysts, while $2 \%$ are technical analysts and $20 \%$ are specialists. Finally, with regard to position, the majority (67\%) are managers (main office, of a branch/unit, or intermediary, executive/business), $10.8 \%$ are coordinators or advisors, and $22.1 \%$ hold other technical positions.

Two 2-factor scales, already validated in two previous studies, were used: the organizational support scale for transfer to work (OSSTW) validated by Correia-Lima, Loiola, Pereira e Gondim (2017), and the organizational learning scale (OLS), validated by Correia-Lima (2016). On both scales the participants indicated how much they agreed with the items, using a Likert scale ranging from 1 (totally disagree) to 5 (totally agree).

OSSTW consists of the MST (factor 1) and PST (factor 2) factors, both with four items (e.g., material resources in sufficient quantity and quality, opportunities for practical application, praise from superiors, tolerance for errors I make in putting learned competencies into practice). The validation study done by Correia-Lima et al. (2017), applied an exploratory factor analysis (EFA). The factor loadings of the items ranged from 0.47 to 0.91 in factor 1 (MST), which explained $49.10 \%$ of the variance, with its internal consistency being high $($ Cronbach $=0.81)$. The factor loadings for factor 2 (PST) ranged from 0.52 to 0.95 , which explained $16.90 \%$ of the variance and also had high internal consistency (Cronbach $=0.83$ ). In another study, Correia-Lima et al. (2017), confirmed the factorial validity of the scale using a confirmatory factor analysis (CFA), which, in addition to showing excellent fit indices of the measurement model to the data, registered factor loadings between 0.52 and 0.95 (factor 1), and from 0.57 to 0.79 (factor 2). Although the factors had proven to be strongly correlated, the analysis of the average variance extracted (AVE $=0.60$ ) of the two factors was greater than the square of the correlation between factors $(r=0.52)$, indicating discriminant validity between them.

The validation studies of the OLS were conducted by Correia-Lima (2016). In the first study, this author applied an EFA to the scale items, extracting two factors that were designated "socialization" and "codification". These factors are strongly and positively correlated $(r=0.52)$ and explain $56.42 \%$ of the variance of the responses to the items. The "socialization" factor was composed of six items (e.g., informal conversations with superiors, participation in problem-solving groups) with factor loadings between 0.59 and 0.78 , as well as good internal consistency (Cronbach $=$ 0.77). The "codification" factor was also composed of six items (e.g., normalization and new processes and work routines, changes in products 
and services), whose factor loadings were between 0.66 and 0.78 , and with high internal consistency (Cronbach $=0.88$ ). This factor structure was confirmed in a subsequent study in which Correia-Lima (2016) applied a CFA, showing the good fit of the measurement model.

In the present study, participants' responses to OSTTS and to the OLS followed the same procedures used in their validation studies mentioned above. In addition to the voluntary acceptance of the participation page and the respondent's demographic data, the questionnaire sent was composed of two blocks of questions. In the first block, the respondents were asked to indicate their level of mastery of 15 competencies (three organizational and 12 individuals, being four managerial and eight functional) two years before and currently, to measure the results of IL, that is, what the individuals learned. The second block presented the two aforementioned scales.

As for the data analysis procedures, the t-test for paired samples was applied, comparing the means of $\mathrm{IL}_{0}\left(\mathrm{M}_{0}\right.$ - Mastery before $)$ and $\mathrm{IL}_{1}\left(\mathrm{M}_{1}\right.$ Mastery after), aiming to measure results of IL of competencies in the last two years (net learning). There was an IL of competencies if and only if the difference $\left(M_{1}-M_{0}\right)$ had a positive (greater than 0$)$ and significant $(p<$ $0.05)$ value, that is, when there were positive changes in the mastery of competencies. The IL construct was represented by the general individual learning (GIL) variable that refers to the current mastery $\left(M_{1}\right)$ that the individuals perceive they have of each of the competencies. To verify the relationship between the variables, multiple regression analysis was used, carried out with SPSS 20.0 software.

\subsection{Results of study 1}

The results are arranged in subsections. In the first one, the levels of perception of the employees regarding IL, OL, and the presence of OST are described. Next, the exploratory tests of the relationships between these variables are presented.

\subsubsection{Perception of IL, OL, and OST in the public bank}

The perceptions of the respondents at the bank indicate that there was IL in the previous two years. While the overall mean mastery of competencies two years before was $4.00\left(\mathrm{M}_{0}\right)$, the current mean was $4.75\left(\mathrm{M}_{1}\right)$. The difference of 0.75 (s. d. 0.52; $p<0.001$ ) between $\mathrm{M}_{1}$ and $\mathrm{M}_{0}$ is statistically 
significant, demonstrating learning in the period. This learning occurred in the three types of competencies: organizational competencies $\left(\mathrm{M}_{0} 3.75 ; \mathrm{M}_{1}\right.$ 4.33; 0.58; s. d. 0.61; $p<0.001)$, managerial competencies $\left(\mathrm{M}_{0} 3.06 ; \mathrm{M}_{1}\right.$ $3.93 ; 0.87 ;$ s. d. $0.62 ; p<0.001)$, and functional competencies $\left(\mathrm{M}_{0} 3.16 ; \mathrm{M}_{1}\right.$ 3.92; 0.76; s. d. 0.53; $p<0.001)$.

There was also OL, according to the perception of the interviewees, in the same time period. The mean values for how much the employees perceived the occurrence of SOC and COD were also significant $(\mathrm{p}<0.05)$, above 3.00, the center point of the scale. The perception of SOC presented a mean of 3.33, standard deviation of 0.74 , and $\mathrm{p}<0.001$, and for COD, a mean of 3.27, s. d. 0.80, and $p<0.001$.

As for the perception of OST promotion, the $t$-test indicated a high level of PST (mean 3.16; s. d. 0.91; $p=0.013$ ), significantly above 3.00, the center point of the scale. The presence of MST was perceived by the employees at moderate levels (mean 2.93; s. d. $0.89 ; p=0.240$ ).

\subsubsection{Relationships between IL, OL (SOC and COD) and OST (MST and PST)}

Figure 4.2.2.1 presents the results of the three stages of multiple linear regression, following the procedures proposed by Kenny and Judd (2014) for testing hypotheses that predict mediation.

The results of the regression of SOC on the independent variable IL indicate a positive relationship between the two variables (Beta $=0.477$; $p<0.001$ ), corroborating H1a: "The greater the IL, the greater the SOC". Next, two models were tested. In the first, IL was positively related to both MST $(0.248 ; p<0.001)$ and PST $(0.316 ; p<0.001)$, so that the greater the perception of IL by the employees, the greater the perception of OST promoted by organization studied. Finally, the second model indicated, in addition to the direct relationship between IL and SOC $(0.351 ; p<0.001)$, that socialization is predicted by PST $(0.300 ; p<0.001)$, but not by MST $(0.123 ; p=0.062)$ corroborating $\mathrm{H} 2 \mathrm{c}$, which predicted that the greater the PST, the greater the SOC, while $\mathrm{H} 2 \mathrm{~b}$ was rejected. 
(Figure 4.2.2.1)

REGRESSION BETWEEN IL AND OL BY SOC, MEDIATED BY MST AND PST

\begin{tabular}{|c|c|c|c|c|}
\hline \multirow{4}{*}{$\begin{array}{l}\text { Predictor } \\
\text { variables }\end{array}$} & \multicolumn{4}{|c|}{ Dependent variables } \\
\hline & \multirow{2}{*}{$\begin{array}{c}\text { Stage 1: } \\
\text { SOC }\end{array}$} & \multicolumn{2}{|c|}{ Stage 2: } & \multirow{2}{*}{$\begin{array}{c}\text { Stage 3: } \\
\text { SOC }\end{array}$} \\
\hline & & MST & PST & \\
\hline & Beta & Beta & Beta & Beta \\
\hline IL & $0.477^{\star \star \star}$ & $0.248^{\star \star \star}$ & $0.316^{\star \star \star}$ & $0.351^{\star \star \star}$ \\
\hline MST & & & & 0.123 \\
\hline \multirow[t]{5}{*}{ PST } & & & & $0.300^{\star \star \star}$ \\
\hline & $R=.477$ & $R=.248$ & $R=.316$ & $R=.352$ \\
\hline & $R^{2} a=.223$ & $R^{2} a=.057$ & $R^{2} a=.096$ & $R^{2} a=.343$ \\
\hline & $F(1.201)=59.14$ & $F(1.201)=13.14$ & $F(1.201)=22.37$ & $F(3.199)=29.40$ \\
\hline & $p=.000$ & $p=.000$ & $p=.000$ & $p=.000$ \\
\hline
\end{tabular}

Beta $=$ standardized regression coefficients. ${ }^{* \star *} p<0.001$

Source: Elaborated by the authors.

It was also observed that the relationship between IL and SOC is mediated by PST (mediated effect $=0.093, p<0.004$ ), corroborating H3c. This mediation means that the more they learn competencies, the more individuals perceive that the organization offers PST. Following on to the process, the greater this perception, the greater is SOC. That is, IL is converted to OL by means of the PST. No MST mediator effect (mediated effect $=0.041 ; p>0.051$ ) was found, and H3a was rejected.

Figure 4.2.2.2 replicates these three stages, considering the codification (COD) variable as a dimension of OL.

The test of the relationship between IL and COD showed a positive relationship (0.359; $p<0.001)$, corroborating H1b: "The greater the IL, the greater COD". Another test shows that IL is positively related with MST $(0.248, p<0.001)$ and also with PST $(0.316 ; p<0.001)$, indicating that the greater the level of IL of competencies, the greater the employees' perceptions about OST promoted by the bank. The last model brought together the three variables (IL, MST, PST) as independent variables. All appear as direct predictors of COD, dimension of OL, dependent variable. These results corroborate hypotheses $\mathrm{H} 2 \mathrm{a}$ "The greater the MST, the greater the COD" - and H2d - "The greater the PST, the greater the COD". 
(Figure 4.2.2.2)

REGRESSION BETWEEN IL AND OL BY COD, MEDIATED BY MST AND PST

\begin{tabular}{|c|c|c|c|c|}
\hline \multirow{4}{*}{$\begin{array}{l}\text { Predictor } \\
\text { variables }\end{array}$} & \multicolumn{4}{|c|}{ Dependent variables } \\
\hline & \multirow{2}{*}{$\frac{\text { Etapa 1: }}{\text { COD }}$} & \multicolumn{2}{|c|}{ Etapa 2: } & \multirow{2}{*}{$\frac{\text { Etapa 3: }}{\text { COD }}$} \\
\hline & & MST & PST & \\
\hline & Beta & Beta & Beta & Beta \\
\hline IL & $0.359^{\star \star \star}$ & $0.248^{\star * *}$ & $0.316^{\star \star \star}$ & $0.209 * \star$ \\
\hline MST & & & & $0.188^{\star \star}$ \\
\hline \multirow[t]{5}{*}{ PST } & & & & $0.327^{\star \star \star}$ \\
\hline & $R=.359$ & $R=.248$ & $R=.316$ & $R=.307$ \\
\hline & $\mathrm{R}^{2} \mathrm{a}=.124$ & $R^{2} a=.057$ & $R^{2} a=.096$ & $R^{2} a=.297$ \\
\hline & $F(1.201)=29.68$ & $F(1.201)=13.14$ & $F(1.201)=22.37$ & $F(3.199)=29.40$ \\
\hline & $p=.000$ & $p=.000$ & $p=.000$ & $p=.000$ \\
\hline
\end{tabular}

Beta $=$ standardized regression coefficients. ${ }^{\star \star} p<0.01,{ }^{* \star *} p<0.001$.

Source: Elaborated by the authors.

MST $(0.069 ; p<0.01)$ and PST $(0.143 ; p<0.01)$ mediate the relationship between IL and COD, also corroborating H3b - "MST mediates the relationship between IL and COD" - and H3d - "PST mediates the relationship between IL and COD". The results indicate that the greater the IL, the more the workers perceive that the organization promotes MST and PST needed for the application of IL at work, and the greater this perception, the greater the perception of COD.

Figure 4.2.2.3 systematizes the results obtained in an analytical model that shows the mediating role of the two types of support for transfer in the relationship between IL, socialization, and codification. As it can be seen, the results of this exploratory study are consistent with the hypotheses that predict the mediation and represent an important step for understanding the conversion of IL into OL. It is necessary, however, to submit the analytical model elaborated here to a more robust test to synthesize the proposed hypotheses, in addition to verifying whether the observed mediated effects are replicated in another sample. Study 2 was conducted to address these concerns. 


\section{(Figure 4.2.2.3)}

RELATIONSHIP BETWEEN IL AND THE DIMENSIONS OF OL

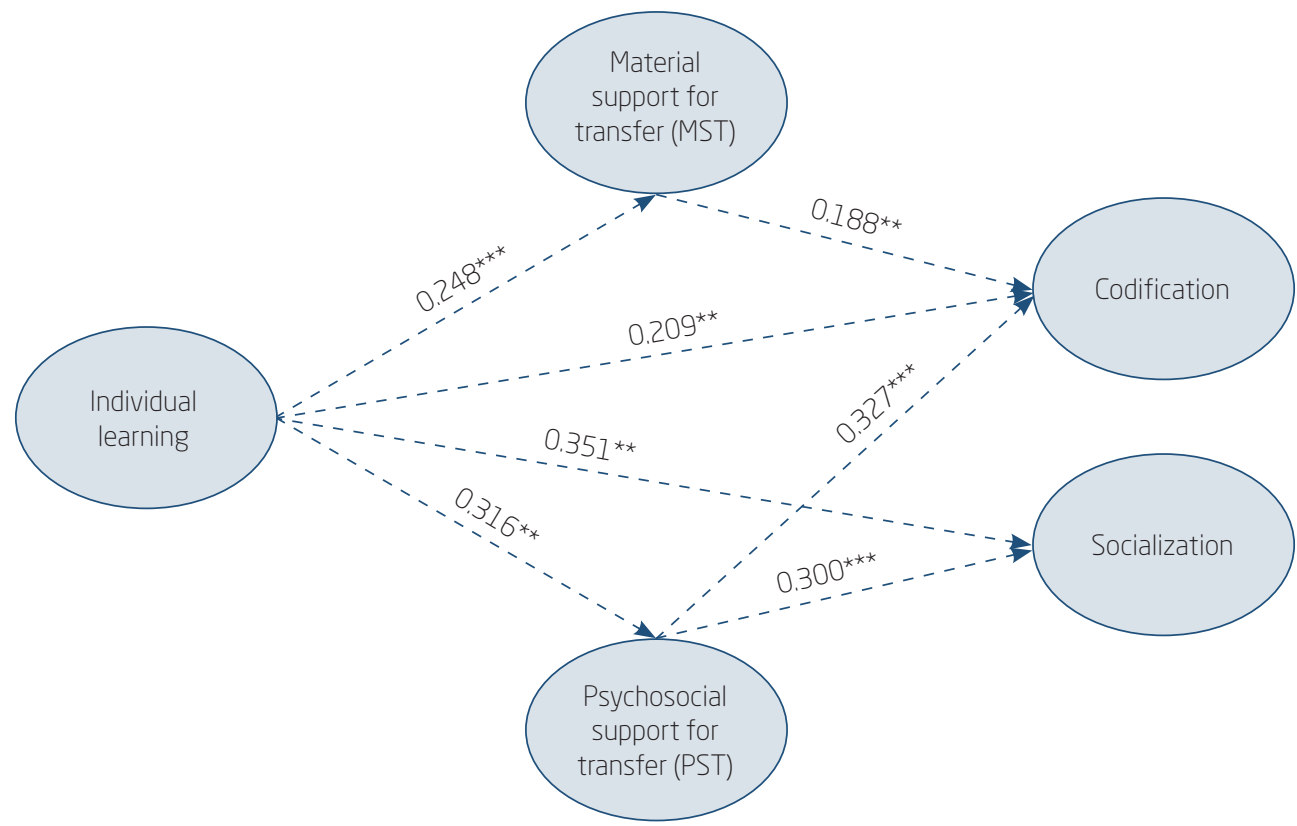

${ }^{\star *} p<0.01,{ }^{* \star *} p<0.001$

Source: Elaborated by the authors.

\section{STUDY 2}

Study 2 was conducted to verify whether the results observed in study 1 are replicable in a sample independent of the one used in study 1 , which could represent an important step in demonstrating that MST and PST actually measure the relationship between IL and OL. Of major importance, the present study assumes a confirmatory character, which allows testing the overall fit of the analytical model developed in study 1 through the use of structural equation modeling with latent variables.

\subsection{Method of study 2}

The CSOPI, where study 2 was conducted, works to promote culture and generate income in the Brazilian Northeast. The only difference in the research instrument applied was the listing of the competencies to measure 
IL. As in the first study, the menu of 12 competencies, with eight being organizational and three managerial, was selected in internal documents of the CSOPI: portal, Competencies Report by Axis, and the book Community life: action, dialogue, and development.

From about 7,000 employees, 1,000 received by e-mail the link to the questionnaire containing the variables that operationalize the model to be tested. The final sample consisted of 252 respondents, being: $52.4 \%$ women and $47.6 \%$ men; $7.9 \%$ over 40 years of age, the rest fall into the age groups between 20 and $30(48 \%)$ and between 31 and $40(44.1 \%)$. They are subdivided into the positions of coordination $(65.1 \%)$, technical assistance $(18.3 \%)$, assistance $(14.7 \%)$, analysis $(1.2 \%)$, management $(0.4 \%)$, and directors $(0.4 \%)$. Most have completed college $(69.4 \%)$, while $12.7 \%$ have done graduate studies, lato sensu. No participant has a Master's or Ph.D. As for the time working in the organization, the majority $(69.1 \%)$ have between 3 and 10 years. The adequacy of the sample size to test the proposed model was analyzed in WebPower (Zhang \& Yuan, 2018) and was indicated to be sufficiently large since it has a test power greater than $99 \%$ to detect a good fit of the model using SEM.

Using the SPSS 20.0 software and the $t$-test, it was identified that there was IL of competencies in the previous two years, as well as OST, SOC, and COD. For SEM, the AMOS 18.0 software was used. The adequacy of the model was assessed according to the following indices of fit (Byrne, 2010): the chi-square per degrees of freedom $\left(\chi^{2} / \mathrm{gl}\right)$ ratio less than 5 , indicating adequate fit; Goodness-of-Fit Index (GFI), Adjusted Goodness-of-Fit Index (AGFI), and Comparative-Fit-Index (CFI) all greater than 0.90, indicating adequacy of the model; Root Mean Square Error of Approximation (RMSEA) less than 0.08 , indicating satisfactory fit of the model. The analysis of the residuals resulting from the application of the model showed that they are normally distributed, which meets the requirements imposed for estimating the parameters with the maximum likelihood method.

\subsection{Results of study 2}

In the subsequent sections, the results of IL, OL, and OST in the CSOPI are presented, as well as testing the model using SEM.

\subsubsection{Perception of IL, OL (SOC and COD) and OST (MST and PST)}

The mean of the mastery of organizational competencies for the CSOPI interviewees increased from $3.54\left(\mathrm{M}_{0}\right)$ to $4.21\left(\mathrm{M}_{1}\right)$. The difference of 0.67 
$\left(\mathrm{M}_{1}-\mathrm{M}_{0}\right)$ is statistically significant (s. d. 0.62, $\left.p<0.001\right)$. Regarding management competencies, the mean of mastery went from $3.27\left(\mathrm{M}_{0}\right)$ to $4.03\left(\mathrm{M}_{1}\right)$. The difference of $0.75\left(\mathrm{M}_{1}-\mathrm{M}_{0}\right)$ is also statistically significant (s. d. $0.73, p<0.001$ ). In general, after two years, the level of mastery of 12 competencies rose from $3.48\left(\mathrm{M}_{0}\right)$ to $4.27\left(\mathrm{M}_{1}\right)$, showing a significant difference $\left(\mathrm{M}_{1}-\mathrm{M}_{0}=0.70, p<0.001\right)$.

The results for SOC (mean 3.63; s. d. 0.70; $p<0.001$ ) and COD (3.69; $0.79 ; p<0.001)$ showed means above the center point of the scale $(3.00)$ and statistically significant. Both types of OST were perceived as high: MST (mean 3.51; s. d. 0.82; $p<0.001$ ) and PST (mean 3.55; s. d. 0.85; $p<0.001$ ).

These data indicate that, according to the perception of CSOPI employees, there was IL, OL, and promotion of OST.

\subsubsection{Relationship between IL, OL (SOC and COD) and OST (MST and PST)}

Figure 5.2.2.1 specifies a model, according to which the relationship between IL and the two dimensions of OL (SOC and COD) is mediated by OST (MST and PST). The results of the global fit of the model to the data show satisfactory indices demonstrating the good fit of the model to explain the relationships between the variables: $\chi^{2}(233)=472.878, p=0.000, \chi^{2} /$ $\mathrm{gl}=2.030$, GFI $=0.871, \mathrm{CFI}=0.940, \mathrm{RMSEA}=0.064(90 \% \mathrm{CI}=0.056$; 0.072). In other words, the proposed mediation model is adequate enough to explain the relationship between IL and OL. 


\section{(Figure 5.2.2.1)}

\section{RELATIONSHIP BETWEEN IL AND THE DIMENSIONS OF OL ${ }^{5}$}

Initial Structural Model
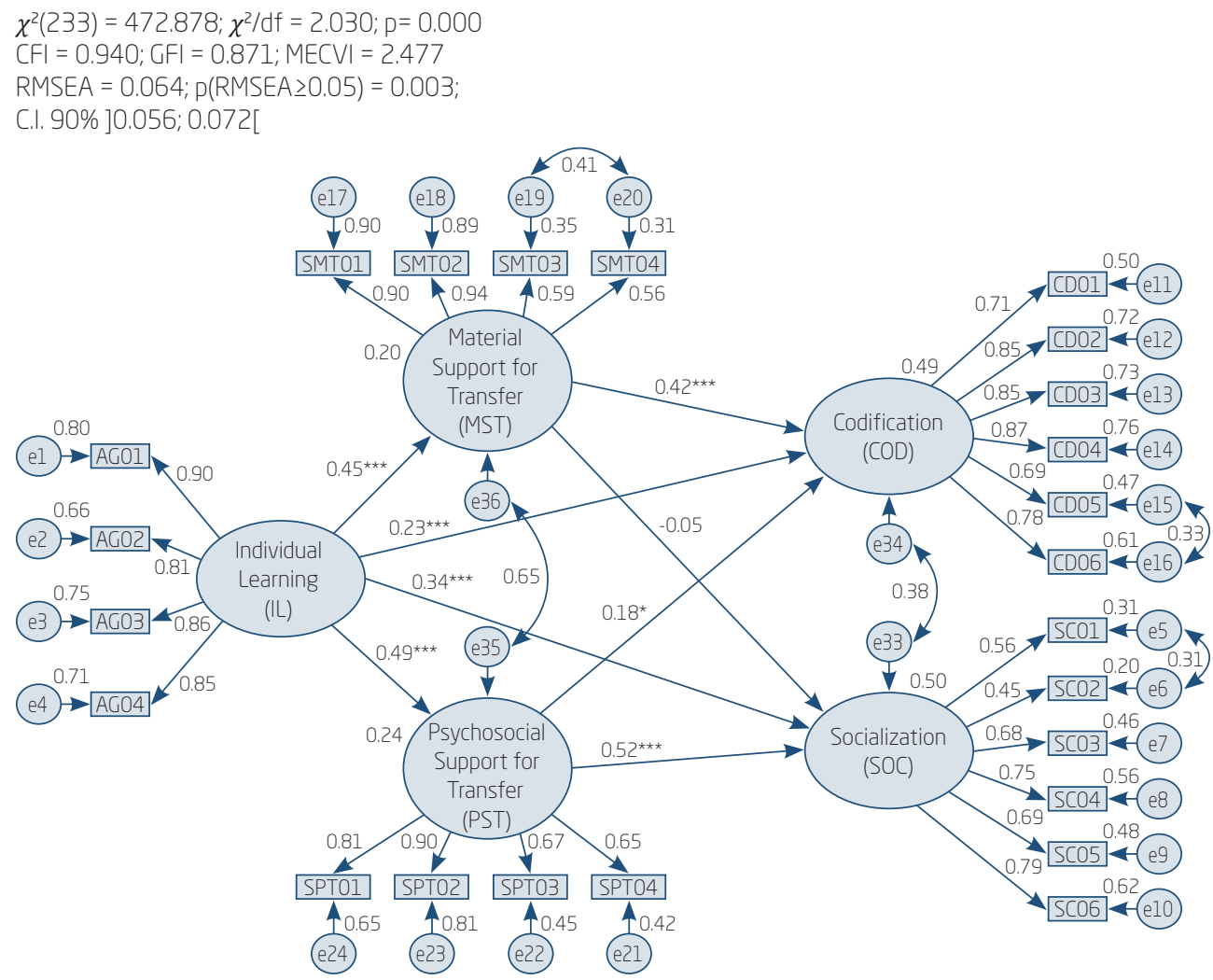

${ }^{\star} p<0.05,{ }^{* \star *} p<0.001$

Source: Elaborated by the authors.

The model results indicate that OL is positively predicted by IL. H1a "The greater the IL, the greater the SOC" $(0.340 ; p<0.001)$ - and H1b - "The greater the IL, the greater the COD" $(0.230 ; p<0.001)$ - are corroborated, results which replicate those of study 1 . Based on these results, it is concluded that H1 - "The greater the IL, the greater the OL" - was accepted.

\footnotetext{
5 The correlations between the errors of measurement and between the residuals of latent variables were freely estimated because the validation studies of the scales indicated a strong correlation between these variables (Correia-Lima, 2016), which indicated the need to take them into account in the specification of models in subsequent studies.
} 
Both types of OST presented positive relationships with COD. The effect of MST on COD $(0.415 ; p<0.001)$ corroborated H2a. Similarly, H2d was also corroborated because PST predicts COD (0.187; 0.041). MST did not appear as a predictor of SOC $(-0.051 ; 0.580)$, with $\mathrm{H} 2 \mathrm{~b}$ being rejected, while PST predicts SOC $(0.518 ; p<0.001)$, making $\mathrm{H} 2 \mathrm{c}$ accepted. These results from study 2 , again, replicate results from study 1 .

Finally, as also observed in the study carried out at the bank, both MST and PST mediate the relationship between IL and COD (mediated effects = $0.25 ; p<.001$ and $0.09 ; p<0.001$, respectively), corroborating $\mathrm{H} 3 \mathrm{~b}$ and $\mathrm{H} 3 \mathrm{~d}$. Like the results obtained for study 1, PST is shown to mediate only the relationship between IL and SOC $(0.233, p<0.001)$, corroborating H3c. H3a - "MST mediates the relationship between IL and SOC" - was not corroborated. In view of these results, we conclude that $\mathrm{H} 3$ was partially corroborated.

\section{DISCUSSION}

Both studies investigate the behavior of variables that are related to learning at the individual and organizational levels, as well as the role of the support for transfer in the inter-level relationship (Figure 6.1). The results reinforce the theoretical postulates that IL is different from OL, that there is no OL without IL, and that for OL to occur, IL has to be applied in the work, socialized and codified, coming to form organizational memory (Argyris \& Schön, 1978; Levitt \& March, 1988).

A positive relationship was observed between IL and OL, both through COD and especially through SOC. This result corroborates findings from previous studies (Popadiuk \& Ayres, 2016; Kotlarsky et al., 2014). It was also found that the greater the SOC of competencies, the greater the COD of competencies, and vice-versa (Leopoldino, 2012; Noe et al., 2014, Correia-Lima 2016).

Evidence that PST predicts SOC adds to findings from previous research (Lin et al., 2012; Catino \& Patriotta, 2013; Tasselli, 2015), although the positive relationship between PST and COD is still little explored. Values, technologies, policies, strategies, and codified procedures are easier to disseminate and practice, representing a source of reference for more productive and ethical employee behaviors, with positive impacts on the performance and image of organizations. The management of PST combined with COD practices can enhance knowledge retention processes in the organization, 
increasing the bases of know-how and know-why, and converging so that operational processes enable organizations to adequately respond to the environmental challenges they encounter.

\section{(Figure 6.1)}

HYPOTHESES TESTED AND RESULTS

\begin{tabular}{|c|c|}
\hline Hypotheses & Results \\
\hline $\mathrm{HI}(\mathrm{IL} \rightarrow \mathrm{OL})$ & Accepted (at the bank and the CSOPI) \\
\hline $\mathrm{HIa}(\mathrm{IL} \rightarrow \mathrm{SOC})$ & Accepted (at the bank and the CSOPI) \\
\hline $\mathrm{HIb}(\mathrm{IL} \rightarrow \mathrm{COD})$ & Accepted (at the bank and the CSOPI) \\
\hline \multicolumn{2}{|l|}{$\mathrm{H} 2(S T \rightarrow O L)$} \\
\hline $\mathrm{H} 2 \mathrm{a}(\mathrm{MST} \rightarrow \mathrm{COD})$ & Accepted (at the bank and the CSOPI) \\
\hline $\mathrm{HZb}(\mathrm{MST} \rightarrow \mathrm{SOC})$ & Rejected (at the bank and the CSOPI) \\
\hline $\mathrm{HZC}(P S T \rightarrow S O C)$ & Accepted (at the bank and the CSOPI) \\
\hline $\mathrm{H} 2 \mathrm{~d}(P S T \rightarrow C O D)$ & Accepted (at the bank and the CSOPI) \\
\hline \multicolumn{2}{|l|}{$\mathrm{H} 3(\mathrm{IL} \rightarrow \mathrm{ST} \rightarrow \mathrm{OL})$} \\
\hline $\mathrm{HBa}(\mathrm{IL} \rightarrow \mathrm{MST} \rightarrow \mathrm{SOC})$ & Rejected (at the bank and the CSOPI) \\
\hline $\mathrm{HBb}(\mathrm{IL} \rightarrow \mathrm{MST} \rightarrow \mathrm{COD})$ & Accepted (at the bank and the CSOPI) \\
\hline $\mathrm{HBC}(\mathrm{IL} \rightarrow \mathrm{PST} \rightarrow \mathrm{SOC})$ & Accepted (at the bank and the CSOPI) \\
\hline $\mathrm{H} 3 \mathrm{~d}(\mathrm{IL} \rightarrow \mathrm{PST} \rightarrow \mathrm{COD})$ & Accepted (at the bank and the CSOPI) \\
\hline
\end{tabular}

Source: Elaborated by the authors.

It was also observed that MST is related to the COD dimension of the OL construct, both at the bank and at the CSOPI, confirming studies by Graciola et al. (2016) and Cacciatori et al. (2011). COD of IL of competencies is also predicted by the PST promoted by the two organizations, confirming the findings of King (2009), Alvarenga and Vieira (2011), Catino and Patriotta (2013), Popadiuk and Ayres (2016). These results reinforce estimates of positive benefits from the combined management of MST and PST and COD practices.

In the two contexts studied, the conversion of IL into OL, in addition to occurring in a direct and significant way, received reinforcement from MST and PST. At the bank and at the CSOPI, the MST acted as a mediator of the conversion of IL of competencies into OL, through COD. While PST played 
the role of mediator of the conversion of IL of competencies into OL, through SOC and, with less force, through COD. These results indicate that the conversion of IL into OL is explained, in part, by the presence of OST, and can be enhanced by appropriate management of these forms of support.

\section{CONCLUSIONS}

The studies presented analyzed the relationship between IL (individual level), OL (organizational level), and OST (organizational support for transfer), demonstrating that there were IL and OL, that IL predicts OL, that socialization and codification convert IL into OL, and that OST mediates and enhances the relationship between IL and OL. The workers from both organizations learned managerial and functional competencies, these competencies were converted into policies, were appropriated in websites, in procedures manuals and work routines of the two organizations studied, and this conversion from IL into OL was favored by support from peers, from superiors, by the existence of appropriate equipment, among other types of OST.

The non-trivial look at the multidimensional and inter-level phenomena of IL and OL and their relationships and mediating variables opens new possibilities in the evaluation of management practices for learning, diversifying and instrumentalizing future decisions of organizational managers, researchers, and consultants. The measurement of results of IL of competencies, acquired both formally and informally, evidenced by the perceived change in competencies mastery over two years, desired by the organization, and of OL, evidenced by the perceived results of SOC and COD of IL of competencies, tacit and explicit, are linked, but independent. These measures do not overlap. In addition, measuring OL related to IL is a methodological advance since, as a rule, research on OL presupposes its existence. Their results also contribute to the improvement of interventions in OL, suggesting the use of OST to enhance IL processes and results, and those of converting IL into OL.

The simultaneous use of exploratory and confirmatory modeling methods gave robustness to the reported results, applied to two independent samples. However, sending the questionnaire via e-mail may have generated biases, hindering the participation of potential respondents who would prefer to be interviewed in person. It is also possible that other variables not studied may intervene in the conversion of IL into OL. In future research, 
the use of other contextual variables, such as management style, competitive and innovation strategies, and those related to the individual, such as commitment, motivation, and satisfaction, are recommended. The exploration of the relationships between IL, OST, and OL in other organizational contexts is also suggested.

\section{O PAPEL DE SUPORTES ORGANIZACIONAIS NA RELAÇÃO ENTRE APRENDIZAGEM INDIVIDUAL E ORGANIZACIONAL}

\section{RESUMO}

Objetivo: Compreender a relação entre resultados de aprendizagem individual de competências (AI) e resultados de aprendizagem organizacional $(\mathrm{AO})$, assim como o papel mediador dos suportes organizacionais à transferência de aprendizagem (SOT) na conversão de AI em AO.

Originalidade/valor: Medida de $\mathrm{AO}$ relacionada à $\mathrm{AI}$, pois, em regra, pesquisas sobre AO pressupõem AI, não se detendo a mensurá-la. Proposição de socialização e de codificação como processos de $\mathrm{AO}$, o que envolve aprendizagens formais e informais, e conhecimentos tácitos e explicitos. Foco na conversão de resultados de AI nas organizações em aprendizagem da organização, permitindo avaliar com mais acurácia os resultados dos investimentos organizacionais em aprendizagem formal e informal, considerando-se a prática corrente de medir exclusivamente T\&D. Proposição do uso de SOT para potencializar processos e resultados de AI e de conversão de AI em AO. O uso simultâneo de métodos exploratórios e confirmatórios de modelagem e de dados de duas diferentes organizações alinha-se às boas práticas no campo de pesquisa.

Design/metodologia/abordagem: As hipóteses foram testadas em dois estudos, realizados com escalas validadas, enviadas por link aos respondentes pelas organizações. O estudo 1, exploratório, envolveu 203 trabalhadores de um banco público; e o estudo 2, confirmatório, 252 trabalhadores de uma organização da sociedade civil de interesse público (Oscip).

Resultados: Os dois estudos evidenciam que houve AI e AO, que AI é aprendizagem líquida de competências desejadas pela organização (AI1-AI0), que AO é fruto da socialização e da codificação de AI aplicada ao trabalho, que AI prediz AO e que SOT medeia a relação entre AI e AO. 


\section{PALAVRAS-CHAVE}

Aprendizagem individual de competências. Aprendizagem organizacional. Socialização. Codificação. Suportes organizacionais à transferência.

\section{REFERENCES}

Aguilera, R. V., Dencker, J. C., \& Yalabik, Z. Y. (2008). Institutions and organizational socialization: Integrating employees in cross-border mergers and acquisitions. In Thought leadership in advancing international business research (pp. 153-189). London: Palgrave Macmillan. doi:10.1057/9780230594234_8

Ahmed, I., \& Nawaz, M. M. (2015). Antecedents and outcomes of perceived organizational support: A literature survey approach. Journal of Management Development, 34(7), 867-880. doi:10.1108/JMD-09-2013-0115

Alvarenga, R. C. D., Neto, \& Vieira, J. L. G. (2011). Knowledge management at Embrapa: Sharing our experience on the building of a collaborative model. Perspectivas em Gestão \& Conhecimento, 1(2), 191-208.

Antonacopoulou, E. P. (2006). The relationship between individual and organizational learning. Management Learning, 37(4), 455-473. doi:10.11 77/1350507606070220

Aragón, M. I. B., Jiménez, D. J., \& Valle, R. S. (2014). Training and performance: The mediating role of organizational learning. Business Research Quarterly, 17(3), 161-173. doi:10.1016/j.cede.2013.05.003

Argyris, C., \& Schön, D. A. (1978). Organizational learning: A theory of action perspective. Wokingham: Addison-Wesley.

Balarin, C. S., Zerbini, T., \& Martins, L. B. (2014). A relação entre suporte à aprendizagem e impacto de treinamento no trabalho. Revista Eletrônica de Administração, 20(2), 341-370. doi:10.1590/1413-2311017201341925

Baranik, L. E., Roling, E. A., \& Eby, L. T. (2010). Why does mentoring work? The role of perceived organizational support. Journal of Vocational Behavior, 76(3), 366-373. doi:10.1016/j.jvb.2009.07.004

Barros Martins, L., Zerbini, T., \& Medina Díaz, F. J. (2018). Estrutura fatorial e propriedades psicométricas da Escala de Suporte à Transferência de Treinamento. Psicologia: Teoria e Pesquisa, 34, 1-9. doi:10.1590/0102.3772e 3452 
Basten, D., \& Haamann, T. (2018). Approaches for organizational learning: A literature review. SAGE Open, 8(3). doi:10.1177/2158244018794224

Bido, D. D. S., Godoy, A. S., Araujo, B. F. V. B. D., \& Louback, J. C. (2010). The articulation among individual, group and organizational learning: A study in the industrial environment. Revista de Administração Mackenzie, $11(2), 68-95$.

Blume, B. D., Ford, J. K., Baldwin, T. T., \& Huang, J. L. (2010). Transfer of training: A meta-analytic review. Journal of Management, 36 (4), 1065-1105. doi:10.1177/0149206309352880

Bontis, N., Crossan, M. M., \& Hulland, J. (2002). Managing an organizational learning system by aligning stocks and flows. Journal of Management Studies, 39(4), 437-469. doi:10.5465/APBPP.1999.27594761

Burk, D. L. (2008). O papel do direito de patentes na codificação do conhecimento. Berkeley Technology Law Journal, 23(3), 1009-1034.

Burnes, B., Cooper, C., \& West, P. (2003). Organisational learning: The new management paradigm? Management Decision, 41 (5), 452-464. doi:10.11 08/00251740310479304

Byrne, B. M. (2010). Multivariate applications series. Structural equation modeling with AMOS: Basic concepts, applications, and programming (2nd ed.). New York: Routledge/Taylor \& Francis Group.

Cacciatori, E., Tamoschus, D., \& Grabher, G. (2012). Transferência de conhecimento entre projetos: Codificação em indústrias criativas, de alta tecnologia e de engenharia. Management Learning, 43 (3), 309-331. doi:10.11 $77 / 1350507611426240$

Catino, M., \& Patriotta, G. (2013). Learning from errors: Cognition, emotions and safety culture in the Italian air force. Organization Studies, 34(4), 437-467. doi:10.1177/0170840612467156

Chan, C. C., Lim, L., \& Keasberry, K. S. (2003). Examining the linkages between team learning behaviors and team performance. The Learning Organization, 10(4), 228-236. doi:10.1108/09696470310476990

Congdon, C., Flynn, D., \& Redman, M. (2014). Equilibrando "nós" e "eu". Revisão de Negócios de Harvard, 92 (10), 50-57.

Correia-Lima, B. C.

(2016) Aprendizagem organizacional, aprendizagem individual e suportes organizacionais: Evidências de validação de escalas e testes de relações interníveis (Tese de doutorado, Universidade Federal da Bahia, Salvador, Bahia, Brasil). Recuperado de http://repositorio.ufba.br/ri/handle/ri/ 24526 
Correia-Lima, B. C., Loiola, E., \& Leopoldino, C. B. (2017). Revisão bibliográfica de escalas de aprendizagem organizacional com foco em seus processos e resultados, em seus enablers ou em aprendizagem e desempenho. Organizações \& Sociedade, 24(82), 509-536. doi:10.1590/1984-9240828

Correia-Lima, B. C., Loiola, E., Pereira, C. R., \& Gondim, S. M. G. (2017). Inventário de Suporte à Aprendizagem Organizacional: Desenvolvimento e evidências de validação. Revista de Administração Contemporânea, 21(5), 710-729. doi:10.1590/1982-7849rac2017160316

Crossan, M. M., Maurer, C. C., \& White, R. E. (2011). Reflections on the 2009 AMR decade award: Do we have a theory of organizational learning? Academy of Management Review, 36(3), 446-460. doi:10.5465/amr.2010. 0544.

DeVellis, R. F. (2003). Factor analysis. In R. F. DeVellis. Scale development: Theory and applications (pp. 115-158). Thousand Oaks: Sage.

Graciola, A. P., Bebber, S., D'Arrigo, F. P., Fachinelli, A. C., Milan, G. S., \& de Toni, D. (2016). Influência do ambiente físico de trabalho na criação do conhecimento nas organizações. Perspectivas em Ciência da Informação, 21 (1), 66-83. doi:10.1590/1981-5344/2407

Ho, L. A. (2008). What affects organizational performance? The linking of learning and knowledge management. Industrial Management $\mathcal{E}$ Data Systems, 108(9), 1234-1254. doi:10.1108/02635570810914919

Illeris, K. (2011). Workplaces and learning. The SAGE handbook of workplace learning, 32-45.

Jyothibabu, C., Farooq, A., \& Bhusan Pradhan, B. (2010). An integrated scale for measuring an organizational learning system. The Learning Organization, 17(4), 303-327. doi:10.1108/09696471011043081

Kenny, D. A., \& Judd, C. M. (2014). Power anomalies in testing mediation. Psychological Science, 25(2), 334-339. doi:10.1177/0956797613502676

Kim, D. H. (1993). The link between individual and organizational learning. MIT Sloan Management Review, 35(1), 37.

King, W. R. (2009). Gestão do conhecimento e aprendizagem organizacional. Boston: Springer.

Kostopoulos, K. C., Spanos, Y. E., \& Prastacos, G. P. (2013). Structure and function of team learning emergence: A multilevel empirical validation. Journal of Management, 39(6), 1430-1461. doi:10.1177/0149206311419366

Kotlarsky, J., Scarbrough, H., \& Oshri, I. (2014). Coordinating expertise across knowledge boundaries in offshore-outsourcing projects: The role of codification. Mis Quarterly, 38(2), 607-627. doi:10.25300 
Le Boterf, G. L. (2003). Desenvolvendo a competência dos profissionais. Porto Alegre: Artmed.

Leopoldino, C. B. (2012). Aprendizagem organizacional sobre tecnologias livres e suporte à transferência (Tese de doutorado, Universidade Federal da Bahia, Salvador, Bahia, Brasil).

Levitt, B., \& March, J. G. (1988). Organizational learning. Annual Review of Sociology, 14(1), 319-338.

Lin, T. C., Wu, S., \& Lu, C. T. (2012). Exploring the affect factors of knowledge sharing behavior: The relations model theory perspective. Expert Systems with Applications, 39(1), 751-764. doi:10.1016/j.eswa.2011.07.068

Loiola, E., Pereira, M. E., \& Gondim, S. (2011). Aprendizagem e mecanismos de aprendizagem de trabalhadores em empresas da fruticultura irrigada do Baixo Médio São Francisco. Gest. Prod, 18(1), 91-104. doi:10.1590/ S0104-530X2011000100007

Manuti, A., Pastore, S., Scardigno, A. F., Giancaspro, M. L., \& Morciano, D. (2015). Formal and informal learning in the workplace: A research review. International Journal of Training and Development, 19(1), 1-17. doi:10.1111/ ijtd. 12044

Mesmer-Magnus, J. R., \& De Church, L. A. (2009). Information sharing and team performance: A meta-analysis. Journal of Applied Psychology, 94(2), 535-546. doi:10.1037/a0013773

Miller, L. (2012). Organizations continue to invest in workplace learning. ASTD State of the Industry Report, 42, 43-48.

Morgado, F. F., Meireles, J. F., Neves, C. M., Amaral, A. C., \& Ferreira, M. E. (2017). Scale development: Ten main limitations and recommendations to improve future research practices. Psicologia: Reflexão e Crítica, 30(1). doi:10.1186/s41155-016-0057-1

Nelson, R., \& Winter, S. (1982). An evolutionary theory of economic change. Cambridge: Belknap Press.

Noe, R. A., Clarke, A. D., \& Klein, H. J. (2014). Learning in the twenty-firstcentury workplace. Annual Review of Organizational Psychology and Organizational Behavior, 1(1), 245-275. doi:10.1146/annurev-orgpsych031413-091321

Odor, H. O. (2018). A literature review on organizational learning and learning organizations. International Journal of Economics \& Management Sciences, 7(1), 1-6. doi:10.4172/2162-6359.1000494 
Ostroff, C., \& Kozlowski, S. W. (1992). Organizational socialization as a learning process: The role of information acquisition. Personnel Psychology, 45(4), 849-874. doi:10.1111/j.1744-6570.1992.tb00971.x

Pereira, L. M. R., Loiola, E., \& Gondim, S. M. G. (2016). Aprendizagem de competências, suporte à transferência de aprendizagem e desempenho docente: evidências de validação de escala e teste de relações. Organizações $\mathcal{E}$ Sociedade, 23 (78), 438-459. doi:10.1590/1984-9230785\%0A\%0A6

Perrot, S., Bauer, T. N., Abonneau, D., Campoy, E., Erdogan, B., \& Liden, R. C. (2014). Organizational socialization tactics and newcomer adjustment. Group \& Organization Management, 39(3), 247-273. doi:10.1177/1059 601114535469

Popadiuk, S., \& Ayres, R. M. S. de M. (2016). Transferência de conhecimento, capacidades de aprendizagem e organizacional em um projeto de software interorganizacional. Organizações E Sociedade, 23(79), 553-570. doi:10.15 90/1984-9230792

Reinhold, S., Gegenfurtner, A., \& Lewalter, D. (2018). Social support and motivation to transfer as predictors of training transfer: Testing full and partial mediation using meta-analytic structural equation modelling. International Journal of Training and Development, 22(1), 1-14. doi:10.1111/ ijtd. 12115

Schilling, M. A., \& Fang, C. (2014). When hubs forget, lie, and play favorites: Interpersonal network structure, information distortion, and organizational learning. Strategic Management Journal, 35(7), 974-994. doi:10.1002 / smj.2142

Sparr, J. L., Knipfer, K., \& Willems, F. (2017). How leaders can get the most out of formal training: The significance of feedback-seeking and reflection as informal learning behaviors. Human Resource Development Quarterly, 28(1), 29-54. doi:10.1002/hrdq. 21263

Takahashi, A. (2017). Towards an understanding of organizational learning processes in development of competences. European Journal of Management Issues, 25(3-4). doi:10.15421/191720

Tasselli, S. (2015). Social networks and inter-professional knowledge transfer. Organization Studies, 36(7), 841-872. doi:10.1177/0170840 614556917

Zhang, Z., \& Yuan, K.-H. (2018). Practical statistical power analysis using WebPower and $R$. Granger: ISDSA Press.

Watkins, K. E., \& Marsick, V. J. (2014). Developing individual and organizational learning capacity. Human Resource Development Quarterly, 25(1), 10-14. 


\section{AUTHOR NOTES}

Bruno C. Correia-Lima, Escola de Administração, Universidade Federal da Bahia (UFBA); Elisabeth Loiola, Escola de Administração, Universidade Federal da Bahia (UFBA); Cicero R. Pereira, Escola de Ciências Sociais e Humanas, Instituto Universitário de Lisboa (ISCTE-IUL); Josimar S. Costa, Centro de Ciências da Comunicação e Gestão, Universidade de Fortaleza (Unifor), and Cláudio B. Leopoldino, Escola de Administração, Universidade Federal da Bahia (UFBA).

Bruno C. Correia-Lima is now professor at Faculdade de Economia, Administração, Atuárias e Contabilidade (Feaac) at Universidade Federal do Ceará (UFC); Elisabeth Loiola is now full professor at Faculdade de Administração at Universidade Federal da Bahia (UFBA); Cicero R. Pereira is now full professor at Centro de Ciências Humanas, Letras e Artes at Universidade Federal da Paraíba (UFPB); Josimar S. Costa is now professor at Centro de Ciências da Comunicação e Gestão at Universidade de Fortaleza (Unifor); Cláudio B. Leopoldino is now professor at Faculdade de Economia, Atuárias e Administração (Feaac) at Universidade Federal do Ceará (UFC).

Correspondence concerning this article should be addressed to Bruno C. Correia-Lima, Rua Marechal Deodoro, 400, Benfica, Fortaleza, Ceará, Brazil, CEP 60020-060.

E-mail: brunocorreialima@ufc.br

\section{EDITORIAL BOARD}

Editors-in-chief

Janette Brunstein

Silvia Marcia Russi de Domênico

Associated Editor

Silvia Marcia Russi de Domênico

Technical Support

Vitória Batista Santos Silva

\section{EDITORIAL PRODUCTION}

Publishing Coordination

Jéssica Dametta

Layout Designer

Emap

Language Editor

Daniel de Almeida Leão

Graphic Designer

Libro 